\begin{tabular}{lll}
\hline Volume 6 & Nomor 1 & April 2018 \\
\hline
\end{tabular}

\title{
Pengaruh Film Pendek melalui Peer Educator terhadap Perilaku Remaja SMA terkait Kesehatan Reproduksi di Kota Semarang
}

\author{
Wahyu Ratri Sukmaningsih*, Sri Achadi Nugraheni**, Apoina Kartini** \\ *Alumni Magister Ilmu Kesehatan Masyarakat Universitas Diponegoro, \\ **Fakultas Kesehatan Masyarakat, Universitas Diponegoro, Semarang \\ Email: wahyuratri1994@gmail.com
}

\section{ABSTRACT}

The issue of sexuality in adolescents occurs because of low reproductive health knowledge and age of first dating at the age of 15-17 years, so it is feared they are at risk of premarital sexual behavior that affects unwanted pregnancy, abortion, sexually transmitted diseases, and HIV/AIDS. The purpose of this study is to analyze the influence of short films through peer educator on the level of knowledge, attitude, and practice of high school adolescents related to reproductive health. The type of research used is experimental, quasi-experimental approach with Nonequivalent Control Group Design. The population is all students of class XI State Senior High School in Semarang City based on criteria. 100 samples of the treatment group and 100 untreated group samples were taken by Purposive Sampling. The independent variable is the giving of short film through peer educator and the dependent variable is the level of knowledge, attitude, and practice. Mann Whitney test as data analysis. The results show that there are differences in the level of knowledge $(p=0,001)$, attitude ( $p=$ $0,023)$, and practice $(p=0,001)$ of high school adolescents related to reproductive health after being given the media between treatment and untreated groups. There were differences in knowledge level change ( $p=0,004)$, attitude ( $p=0,019)$, and practice $(p=0,001)$ of high school adolescents related to reproductive health between intervention and control groups. The mean in the treatment group was higher than the untreated group. This suggests that short films through peer educators and leaflets are more effective in enhancing knowledge, attitudes, and practices of high school adolescents related to reproductive health than with leaflets. Changes in respondent practice can be see within a minimum of two months. This method in an effort to prevent risky sexual behavior is expected to be applied in schools.

Keywords: Adolescents; Peer Educator; Risky Sexual Behavior

\section{PENDAHULUAN}

Salah satu masalah yang menonjol di kalangan remaja yaitu seksualitas. Permasalahan seksualitas terjadi karena rendahnya pengetahuan remaja tentang 
kesehatan reproduksi. Proporsi terbesar berpacaran pertama kali yaitu pada umur 15-17 tahun, dikhawatirkan mereka berisiko melakukan hubungan seks pranikah yang menempatkan berbagai masalah kesehatan reproduksi seperti kehamilan yang tidak diinginkan (KTD), aborsi, dan HIV/AIDS. ${ }^{1,2}$

Hasil survei Perkumpulan Keluarga Berencana Indonesia (PKBI) Jawa Tengah menunjukkan sekitar 29\% remaja setuju hubungan seks pranikah, 12,54\% responden gaya berpacaran kurang baik, $75,2 \%$ memiliki perilaku seks berisiko, 40\% mengaku sudah pernah pacaran dan $73,3 \%$ di antaranya mulai pacaran dari umur 10-15 tahun. Di antara remaja yang pernah pacaran $11,2 \%$ diantaranya, mengaku sudah pernah memegang organ reproduksi pasangannya. ${ }^{3}$

Salah satu upaya yang dapat dilakukan adalah memberikan pendidikan kesehatan dengan film pendek sebagai inovasi media untuk meningkatkan perilaku remaja SMA tentang kesehatan reproduksi karena terdapat studi yang menunjukkan bahwa seseorang lebih dapat mengingat dari apa yang didengar dan dilihat dibandingkan hanya dengan mendengar atau hanya melihat saja. ${ }^{4}$

Pengaruh keterlibatan kelompok sebaya penting dikarenakan remaja lebih sering berada di luar rumah bersama dengan teman sebaya dan karena sifatnya sensitif, remaja cenderung dan merasa lebih nyaman untuk mengkonsultasikan masalah mengenai permasalahan kesehatan reproduksi kepada temannya dibanding kepada orang tua dan gurunya. Oleh karena itu, perlu adanya keterlibatan peer educator yang dalam pelaksanaannya diberikan pelatihan terlebih dahulu oleh fasilitator di sekolah agar program pendidikan kesehatan reproduksi berjalan secara berkelanjutan sehingga dapat memberikan perubahan yang positif pada diri remaja.

\section{METODE PENELITIAN}

$\begin{array}{ccr}\text { Jenis } & \text { penelitian } & \text { adalah } \\ \text { eksperimental, } & \text { pendekatan } & \text { kuasi }\end{array}$ eksperimen dengan rancangan Nonequivalent Control Group Design. Penelitian dilakukan pada bulan Maret-Mei 2018. Pengumpulan data menggunakan kuesioner (self-administered questionnaire). Populasi yaitu seluruh siswa kelas XI SMA Negeri di Kota Semarang berdasarkan kriteria. 100 sampel kelompok perlakuan (SMAN 15 Semarang) dan 100 sampel kelompok tanpa perlakuan (SMAN 8 Semarang) diambil secara Purposive Sampling. Pada kelompok perlakuan diberikan media film pendek yang disajikan selama 4 menit dan diberikan leaflet untuk dibaca kemudian dilanjutkan diskusi dan tanya jawab antara responden dengan peer educator selama 15 menit, sedangkan pada kelompok tanpa perlakuan diberikan media leaflet untuk dibaca tanpa ada diskusi dan tanya jawab selama 10 menit. Analisis data yang digunakan uji Mann Whitney.

\section{HASIL DAN PEMBAHASAN}

Hasil Penelitian

Deskripsi dan Analisis Homogenitas Karakteristik Responden

Pada kelompok perlakuan maupun kelompok tanpa perlakuan, sebagian besar responden berumur 16 dan 17 tahun, berjenis kelamin perempuan, dan semua sudah pernah memperoleh informasi terkait kesehatan reproduksi dari guru dan media elektronik. 
Data variabel umur, jenis kelamin, dan sumber informasi responden antara kelompok perlakuan dan kelompok tanpa perlakuan mempunyai varian yang sama (homogen).

Deskripsi Tingkat Pengetahuan, Sikap, dan Praktik Remaja SMA terkait Kesehatan Reproduksi Sebelum dan Setelah Diberikan Media pada Kelompok Perlakuan dan Kelompok Tanpa Perlakuan

a. Tingkat Pengetahuan terkait Kesehatan Reproduksi

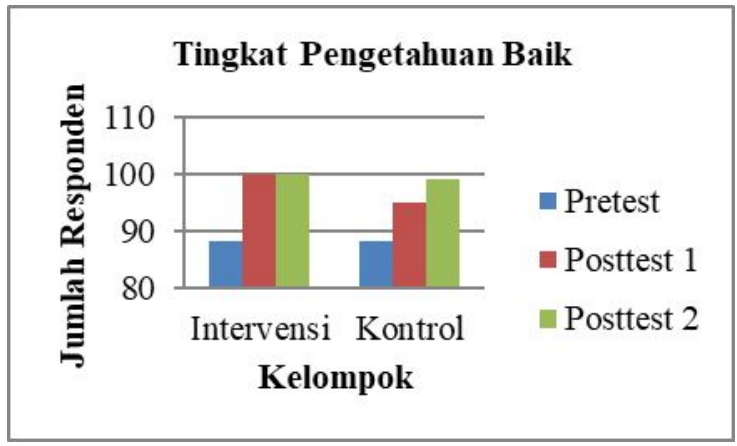

Gambar 1 Tingkat Pengetahuan

Pada kelompok perlakuan dan kelompok tanpa perlakuan, responden yang tingkat pengetahuannya baik mengalami peningkatan dari pretest ke posttest 1 , dan ke posttest 2 .

b. Sikap terkait Kesehatan Reproduksi

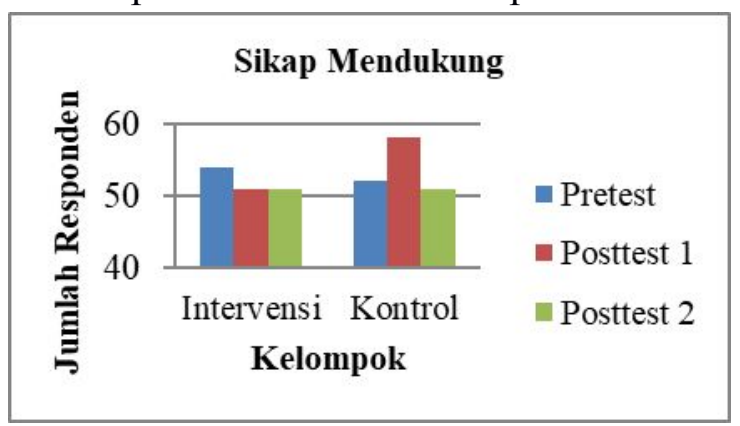

Gambar 2 Sikap terkait Kesehatan

Reproduksi

Pada kelompok perlakuan maupun kelompok tanpa perlakuan, responden yang memiliki sikap mendukung terhadap pencegahan perilaku seksual berisiko mengalami penurunan dari pretest ke posttest 1 , dan ke posttest 2 .

c. Praktik terkait Kesehatan Reproduksi

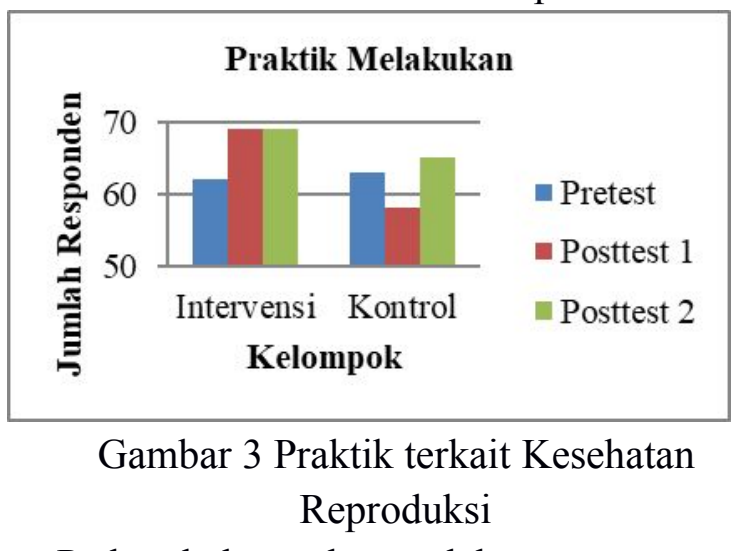

Pada kelompok perlakuan maupun kelompok tanpa perlakuan, responden yang melakukan praktik pencegahan perilaku seksual berisiko mengalami peningkatan dari pretest ke posttest 1 , dan ke posttest 2 .

Analisis Homogenitas Tingkat Pengetahuan, Sikap, dan Praktik Remaja SMA terkait Kesehatan Reproduksi Sebelum Diberikan Media antara Kelompok Perlakuan dan Kelompok Tanpa Perlakuan

Berdasarkan analisis homogenitas menggunakan uji Mann Whitney diketahui bahwa data variabel tingkat pengetahuan $(p=0,121)$, sikap $(p=0,854)$, dan praktik $(p=0,613)$ remaja SMA terkait kesehatan reproduksi sebelum diberikan media antara kelompok perlakuan dan kelompok tanpa perlakuan mempunyai varian yang sama (homogen). 


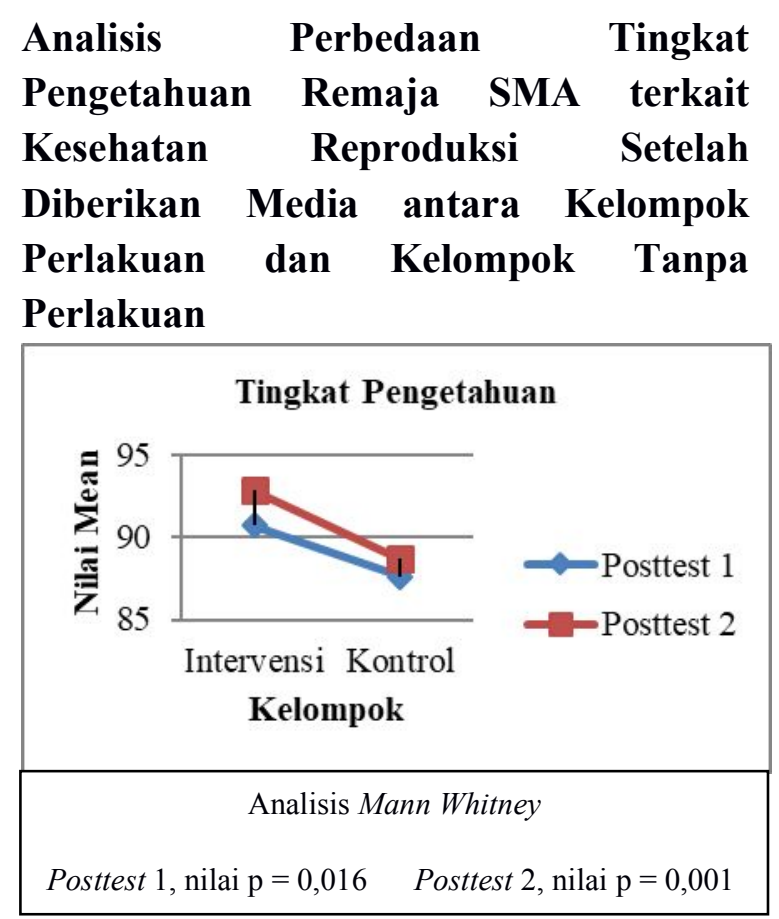

Gambar 4 Perbedaan Tingkat Pengetahuan

Setelah Diberikan Media

Ada perbedaan tingkat pengetahuan remaja SMA yang signifikan terkait kesehatan reproduksi setelah diberikan media antara kelompok perlakuan dan kelompok tanpa perlakuan $(\mathrm{p}=0,001)$.

\section{Analisis Perbedaan Sikap Remaja SMA terkait Kesehatan Reproduksi Setelah Diberikan Media antara Kelompok Perlakuan dan Kelompok Tanpa Perlakuan}

\begin{tabular}{|c|c|c|c|c|}
\hline \multicolumn{5}{|c|}{ Sikap } \\
\hline 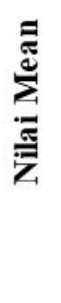 & \multicolumn{3}{|c|}{ Kelompok } & $\begin{array}{l}- \text { Posttest } 1 \\
- \text { Posttest } 2\end{array}$ \\
\hline \multicolumn{5}{|c|}{ Analisis Mann Whitney } \\
\hline \multicolumn{3}{|c|}{ Posttest 1 , nilai $\mathrm{p}=0,003$} & Post & st 2 , nilai $\mathrm{p}=0,023$ \\
\hline
\end{tabular}

Ada perbedaan sikap remaja SMA yang signifikan terkait kesehatan reproduksi setelah diberikan media antara kelompok perlakuan dan kelompok tanpa perlakuan $(p=0,023)$.

Analisis Perbedaan Praktik Remaja SMA terkait Kesehatan Reproduksi Setelah Diberikan Media antara Kelompok Perlakuan dan Kelompok Tanpa perlakuan

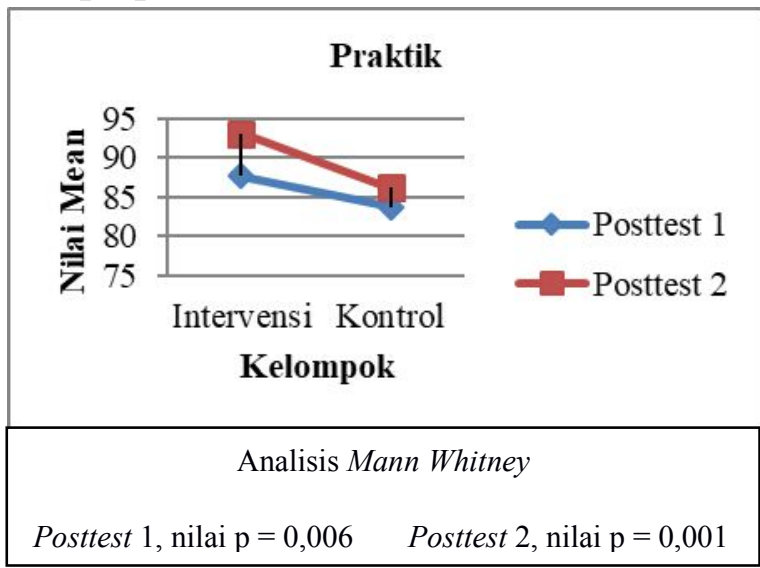

Gambar 6 Perbedaan Praktik Setelah

Diberikan Media

Ada perbedaan praktik remaja SMA yang signifikan terkait kesehatan reproduksi setelah diberikan media antara kelompok perlakuan dan kelompok tanpa perlakuan $(p=0,001)$.

Analisis Perbedaan Perubahan Tingkat Pengetahuan Remaja SMA terkait Kesehatan Reproduksi antara Kelompok Perlakuan dan Kelompok Tanpa Perlakuan 


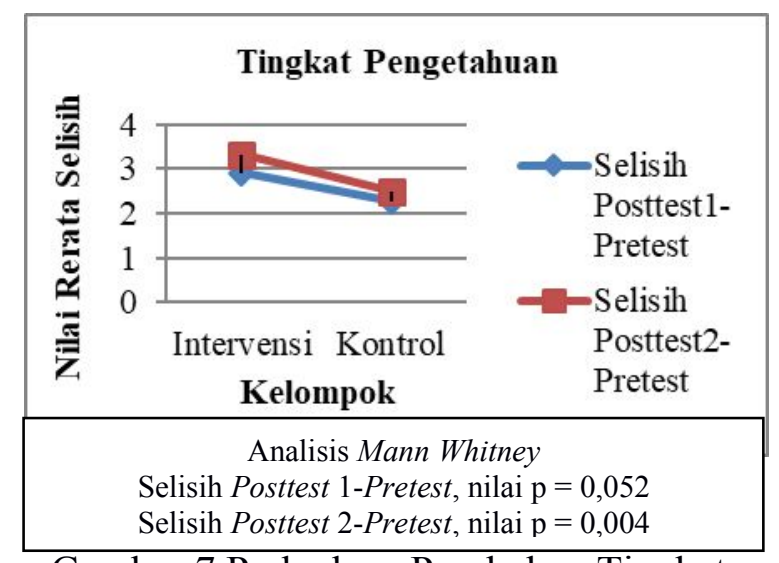

Gambar 7 Perbedaan Perubahan Tingkat

Pengetahuan

Ada perbedaan perubahan tingkat pengetahuan remaja SMA yang signifikan terkait kesehatan reproduksi antara kelompok perlakuan dan kelompok tanpa perlakuan $(p=0,004)$. Nilai rerata selisih tingkat pengetahuan pada kelompok perlakuan $(3,32)$ lebih tinggi dibandingkan pada kelompok tanpa perlakuan $(2,49)$.

\section{Analisis Perbedaan Perubahan Sikap Remaja SMA terkait Kesehatan Reproduksi antara Kelompok Perlakuan dan Kelompok Tanpa Perlakuan}

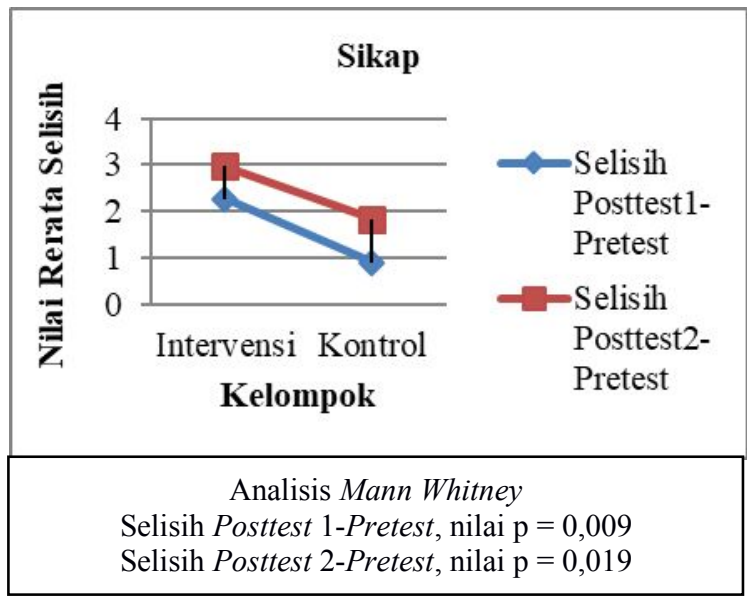

Gambar 8 Perbedaan Perubahan Sikap

Ada perbedaan perubahan sikap remaja SMA yang signifikan terkait kesehatan reproduksi antara kelompok perlakuan dan kelompok tanpa perlakuan $(p=0,019)$. Nilai rerata selisih sikap pada kelompok perlakuan $(2,97)$ lebih tinggi dibandingkan pada kelompok tanpa perlakuan $(1,84)$.

\section{Analisis Perbedaan Perubahan Praktik Remaja SMA terkait Kesehatan Reproduksi antara Kelompok Perlakuan dan Kelompok Tanpa Perlakuan}

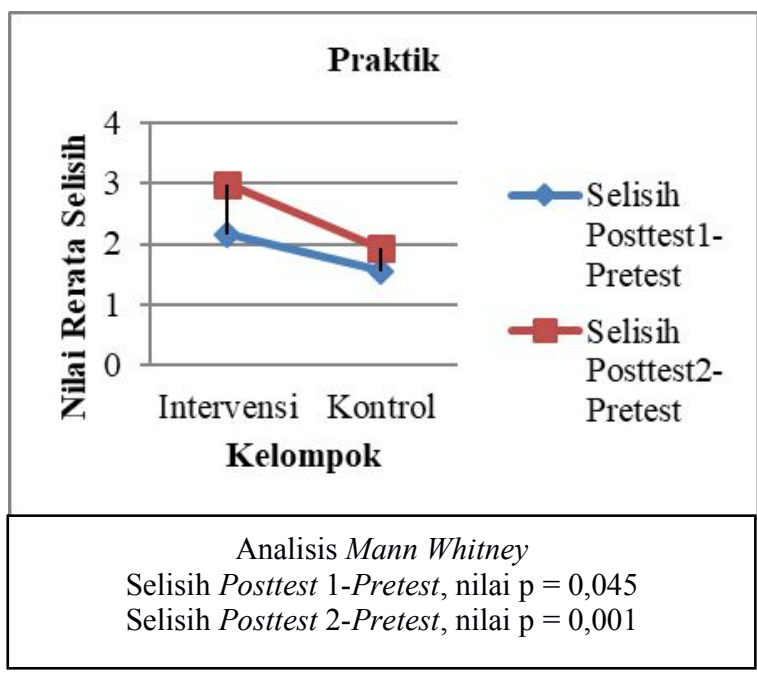

Gambar 9 Perbedaan Perubahan Praktik

Ada perbedaan perubahan praktik remaja SMA yang signifikan terkait kesehatan reproduksi antara kelompok perlakuan dan kelompok tanpa perlakuan $(p=0,001)$. Nilai rerata selisih praktik pada kelompok perlakuan $(2,98)$ lebih tinggi dibandingkan pada kelompok tanpa perlakuan $(1,92)$.

Pembahasan

$\begin{array}{lcr}\text { Analisis } & \text { Perbedaan } & \text { Tingkat } \\ \text { Pengetahuan } & \text { Remaja SMA } & \text { terkait } \\ \text { Kesehatan } & \text { Reproduksi } & \text { Setelah } \\ \text { Diberikan } & \text { Media antara } & \text { Kelompok }\end{array}$




\section{Perlakuan dan Kelompok Tanpa Perlakuan}

Ada perbedaan tingkat pengetahuan remaja SMA yang signifikan terkait kesehatan reproduksi setelah diberikan media antara kelompok perlakuan dan kelompok tanpa perlakuan. Sesuai dengan beberapa penelitian yang menunjukkan hasil adanya perbedaan pengetahuan setelah diberikan perlakuan pada kelompok eksperimen dan kelompok tanpa perlakuan dengan rata-rata skor pengetahuan kelompok pemutaran film lebih besar dibandingkan dengan kelompok leaflet. ${ }^{5,6}$

Tingkat pengetahuan seseorang tentang perilaku seks pranikah dipengaruhi oleh pendidikan kesehatan reproduksi berpengaruh yang diberikan. Keberhasilan dan keefektifan berlangsungnya penyuluhan bergantung pada alat atau sarana yang mudah digunakan dan dipahami oleh penyuluh maupun obyek sasaran. Dalam hal ini media film merupakan salah satu model promosi kesehatan yang kreatif dan inovatif sehingga membuat terjadinya transfer of knowledge menjadi lebih baik dan efektif, materi yang disampaikan menjadi tidak monoton, dan tidak membosankan. Selain itu, dengan adanya peran peer educator memudahkan siswa untuk mendapatkan informasi terkait kesehatan reproduksi secara lebih menyeluruh tanpa adanya kecanggungan. ${ }^{4}$

Sejalan dengan beberapa hasil penelitian yang menunjukkan bahwa rerata pengetahuan antara kelompok yang mendapat pendidikan kesehatan reproduksi oleh pendidik sebaya (peer educator) signifikan berbeda sesudah perlakuan., ${ }^{7,8}$ Rendahnya tingkat pengetahuan seseorang akan lebih mudah untuk melakukan hubungan seks lebih dini. Hal ini dikarenakan tingkah laku manusia hanya ditentukan oleh kemampuan berfikirnya. Seseorang yang pendidikannya semakin tinggi, maka perbuatannya untuk memenuhi keinginan atau kebutuhannya juga semakin baik. ${ }^{9}$

Analisis Perbedaan Sikap Remaja SMA terkait Kesehatan Reproduksi Setelah Diberikan Media antara Kelompok Perlakuan dan Kelompok Tanpa Perlakuan

Ada perbedaan sikap remaja SMA yang signifikan terkait kesehatan reproduksi setelah diberikan media antara kelompok perlakuan dan kelompok tanpa perlakuan. Hal ini sesuai dengan penelitian Rahmawati, dkk menyebutkan bahwa pengetahuan responden meningkat setelah diberikan penyuluhan dengan menggunakan media audio visual, karena penyuluh menggunakan semua alat indera responden sehingga dapat meningkatkan sikap responden dan mengubah perilaku menjadi positif. ${ }^{10}$

Selain itu, penelitian Oktarina, dkk menyatakan bahwa terdapat perbedaan rerata sikap posttest pada kelompok yang diberikan pendidikan kesehatan reproduksi oleh pendidik sebaya dengan kelompok tanpa perlakuan. Dalam hal ini, sikap teman sebaya sangat berpengaruh terhadap praktik seseorang kaitannya dengan seksualitas. $^{7}$

Sikap yaitu suatu tanggapan seseorang yang tertutup terhadap suatu objek menyangkut gagasan dan perasaan seperti bahagia-tidak bahagia, sepakattidak sepakat, dan lainnya. Selain itu, sikap termasuk faktor predisposisi yang mempengaruhi terbentuknya perilaku. ${ }^{9}$

Analisis Perbedaan Praktik Remaja SMA terkait Kesehatan Reproduksi Setelah Diberikan Media antara Kelompok Perlakuan dan Kelompok Tanpa Perlakuan 
Ada perbedaan praktik remaja SMA yang signifikan terkait kesehatan reproduksi setelah diberikan media antara kelompok perlakuan dan kelompok tanpa perlakuan. Praktik merupakan tahap seseorang mengimplementasikan dari inovasi yang mereka terima kemudian mengkonfirmasi atau mengevaluasinya sehingga muncul kemungkinan seseorang untuk menolak atau menerima inovasi tersebut. Praktik siswa SMA yang baik tidak hanya diperoleh dari penyuluhan saja, melainkan dari pengalaman maupun inovasi dari berbagai media informasi seperti halnya film pendek.

Sesuai dengan penelitian Marlita diperoleh bahwa ada perubahan praktik seksual ke arah yang lebih baik setelah diberikannya perlakuan peer education pada kelompok perlakuan $(p=0,000) .{ }^{11}$

Peneliti menganalisis bahwa peer education sangat efektif karena dapat mengubah perilaku seksual remaja berdasarkan pengetahuan, sikap, dan praktik ke arah yang lebih positif. Untuk itu, perlakuan peer education dapat diterapkan secara berkelanjutan dalam upaya pencegahan remaja terhadap perilaku seksual serta memanfaatkan inovasi media yang baru berupa film pendek.

Analisis Perbedaan Perubahan Tingkat Pengetahuan Remaja SMA terkait Kesehatan Reproduksi antara Kelompok Perlakuan dan Kelompok Tanpa Perlakuan

Ada perbedaan perubahan tingkat pengetahuan remaja SMA yang signifikan terkait kesehatan reproduksi antara kelompok perlakuan dan kelompok tanpa perlakuan. Pemberian film pendek melalui peer educator dan leaflet lebih efektif dalam meningkatkan pengetahuan remaja
SMA terkait kesehatan reproduksi dibandingkan dengan pemberian leaflet.

Namun jika dibandingkan pada posttest ke-1 yang diukur pada waktu yang sama dengan pretest diperoleh nilai $\mathrm{p}=$ 0,052 yang menunjukkan tidak ada perbedaan perubahan tingkat pengetahuan, sehingga dalam hal ini dapat disimpulkan bahwa pengukuran pada posttest ke-2 yaitu setelah satu bulan sudah dapat untuk melihat perbedaan perubahan tingkat pengetahuan yang signifikan.

Hasil penelitian ini sesuai dengan penelitian terdahulu yang menunjukkan bahwa media film dengan ceramah dan leaflet lebih efektif untuk meningkatkan pengetahuan tentang kesehatan reproduksi pada remaja dibandingkan pemberian leaflet saja. ${ }^{12,13}$

Pada penelitian ini, pemberian media film pendek dan leaflet lebih efektif meningkatkan pengetahuan tentang kesehatan reproduksi pada siswa SMAN di Kota Semarang dibandingkan hanya dengan media leaflet saja. Hal ini terlihat dari nilai rata-rata tingkat pengetahuan kelompok yang mendapatkan media film pendek dan leaflet lebih tinggi dibandingkan kelompok yang mendapatkan leaflet.

Sebagian besar siswa tertarik untuk melihat dan memperhatikan materi yang disajikan melalui film pendek kemudian sikap interaktif antara siswa dengan peer educator yang baik. Berbeda dengan kelompok yang mendapat leaflet saja, siswa lebih diam dan hanya membaca karena tidak ada sesi diskusi sehingga siswa kurang aktif, tidak dapat bertanya tentang materi yang belum dipahami kepada peer educator.

Sejalan dengan penelitian terdahulu diketahui bahwa terdapat perbedaan perubahan pengetahuan tentang seksual 
remaja antara kelompok perlakuan dengan kelompok tanpa perlakuan setelah diberikan perlakuan peer education. ${ }^{11}$ Perubahan pengetahuan dapat diperoleh dengan memberikan pendidikan kesehatan reproduksi dalam waktu yang pendek. Selain itu, penggunaan metode dan media yang tepat dengan kemasan serta kalimat yang menarik akan mempengaruhi dalam keberhasilan penyampaian suatu pesan. ${ }^{9}$

\section{Analisis Perbedaan Perubahan Sikap Remaja SMA terkait Kesehatan Reproduksi antara Kelompok Perlakuan dan Kelompok Tanpa Perlakuan}

Ada perbedaan perubahan sikap remaja SMA yang signifikan terkait kesehatan reproduksi antara kelompok perlakuan dan kelompok tanpa perlakuan. Pemberian film pendek melalui peer educator dan leaflet lebih efektif dalam meningkatkan sikap remaja SMA terkait kesehatan reproduksi dibandingkan dengan pemberian leaflet.

Pada penelitian ini, pengukuran sikap baik pada saat posttest ke-1 maupun posttest ke-2 sudah dapat melihat perbedaan perubahan sikap yang signifikan, sehingga dapat disimpulkan bahwa dalam waktu satu bulan sudah dapat untuk melihat perbedaan perubahan sikap yang signifikan.

Hal ini sesuai dengan hasil penelitian Marlian yang menunjukkan bahwa ada perbedaan selisih antara sikap terhadap perilaku seks pada kelompok perlakuan dan kelompok tanpa perlakuan. Pada kelompok perlakuan dan kelompok tanpa perlakuan terdapat perbedaan pada pemberian input pengetahuan berupa pemberian media film pendek yang dilakukan oleh peer educator serta ceramah dan diskusi tanya jawab terkait kesehatan reproduksi pada kelompok perlakuan, sedangkan pada kelompok tanpa perlakuan hanya diberikan leaflet. ${ }^{14}$

Selain itu, hasil penelitian menyebutkan bahwa kelompok peer education lebih efektif dan dapat memberi pengaruh pada peningkatan sikap remaja dalam upaya mencegah HIV/AIDS dan KTD. ${ }^{7,11}$

\section{Analisis Perbedaan Perubahan Praktik Remaja SMA terkait Kesehatan Reproduksi antara Kelompok Perlakuan dan Kelompok Tanpa Perlakuan}

Ada perbedaan perubahan praktik remaja SMA yang signifikan terkait kesehatan reproduksi antara kelompok perlakuan dan kelompok tanpa perlakuan. Pemberian film pendek melalui peer educator dan leaflet lebih efektif dalam meningkatkan praktik remaja SMA terkait kesehatan reproduksi dibandingkan dengan pemberian leaflet.

Pada penelitian ini, pengukuran praktik baik setelah satu bulan (posttest 1) maupun setelah dua bulan (posttest 2) diperoleh nilai $\mathrm{p}<0,05$ yang menunjukkan ada perbedaan perubahan praktik terkait kesehatan reproduksi. Namun pada posttest ke-1 menunjukkan perbedaan perubahan yang tidak signifikan jika dibandingkan dengan posttest ke-2, sehingga dapat disimpulkan bahwa pengukuran setelah dua bulan sudah dapat untuk melihat perbedaan perubahan praktik yang signifikan.

Hal ini sesuai dengan penelitian Marlita yang menunjukkan bahwa terdapat perbedaan selisih praktik seksual sesudah dilakukan perlakuan peer education antara kelompok perlakuan dan kelompok tanpa perlakuan. ${ }^{11}$ 
Pada penelitian ini, praktik seksual remaja sebelum diberikan perlakuan film pendek melalui peer educator dan leaflet pada kelompok perlakuan sama dengan praktik seksual remaja sebelum diberikan leaflet pada kelompok tanpa perlakuan. Perilaku seksual juga dipengaruhi oleh berbagai faktor yaitu pengetahuan, sikap, dan praktik. Pengetahuan tentang perilaku seksual penting bagi remaja untuk bisa beradaptasi menghadapi perubahan dalam dirinya.

Pada penelitian ini, besarnya keingintahuan remaja terkait seksualitas menyebabkan remaja selalu berusaha mencari tahu lebih banyak informasi mengenai seksualitas. Pengetahuan yang diperoleh dari informasi yang tidak kompeten akan mempengaruhi persepsi dan sikap remaja terhadap perilaku seksual sehingga akan mendorong remaja untuk melakukan aktivitas seksual.

Dari uraian di atas, peneliti menganalisis bahwa perlunya remaja dibekali dengan pengetahuan terkait kesehatan reproduksi salah satunya dengan metode peer education yang mana penyampaian informasi dilakukan dengan pendekatan komunikasi, informasi, dan edukasi mengedepankan upaya prevensi dan promosi sehingga dapat mengubah sikap dan praktik remaja dalam upaya pencegahan terhadap perilaku seksual pranikah.

Keberhasilan penyampaian informasi melalui peer education dalam penelitian ini mampu mengubah perilaku remaja terkait perilaku seksual karena penyampaian informasi peer educator yang bagus dan mampu menguasai materi saat memberikan pendidikan kesehatan kepada teman-temannya.

Peer educator dalam penelitian ini dapat menjadi solusi permasalahan yang banyak dialami remaja terkait perilaku seksual karena bagi remaja teman adalah orang yang terpercaya dibandingkan orang tua. Teman sebaya memiliki peran yang cukup penting dalam perkembangan remaja, karena remaja lebih banyak berada di luar rumah bersama dengan temanteman sebaya, sehingga dapat mempengaruhi sikap, pembicaraan, penampilan, dan perilaku remaja daripada pengaruh keluarga. ${ }^{15}$

\section{KESIMPULAN}

Hasil penelitian menunjukkan umur, jenis kelamin, dan sumber informasi responden antara kelompok perlakuan dan kelompok tanpa perlakuan mempunyai varian yang sama (homogen). Data variabel tingkat pengetahuan, sikap, dan praktik remaja SMA terkait kesehatan reproduksi sebelum diberikan media antara kelompok perlakuan dan kelompok tanpa perlakuan mempunyai varian yang sama (homogen).

Ada perbedaan tingkat pengetahuan, sikap, praktik, perubahan sikap dan perubahan praktik remaja SMA terkait kesehatan reproduksi setelah diberikan media antara kelompok perlakuan dan kelompok tanpa perlakuan.

\section{UCAPAN TERIMAKASIH}

Penulis mengucapkan terima kasih kepada MIKM FKM UNDIP, SMAN 15 Semarang dan SMAN 8 Semarang atas diijinkannya melakukan penelitian ini.

\section{DAFTAR PUSTAKA}

1. Survei Demografi dan Kesehatan Indonesia. Kesehatan Reproduksi Remaja. Jakarta: Badan Kependudukan dan Keluarga Berencana Nasional, Badan Pusat Statistik, Kementerian Kesehatan, 
MEASURE DHS ICF International; 2012.

2. Kementerian Kesehatan Republik Indonesia Pusat Data dan Informasi. Situasi Kesehatan Reproduksi Remaja. Jakarta: Kemenkes RI; 2012.

3. Kesehatan Reproduksi Remaja. [Internet]. 2016. [diakses tanggal 7 Agustus 2017] Dari: http://www.pkbijateng.or.id.html

4. Kholid A. Promosi Kesehatan dengan Pendekatan Teori Perilaku, Media, dan Aplikasinya. Jakarta: PT RajaGrafindo Persada; 2012.

5. Yulfitria F. Pengaruh Pendidikan Kesehatan dalam Meningkatkan Pengetahuan tentang Pencegahan Keputihan Patologis. Jurnal Bidan "Midwife Journal". Juli 2017; 3 (2).

6. Wibowo, GS. Perbedaan Pengetahuan HIVIAIDS pada Remaja Sekolah dengan Metode Pemutaran Film dan Metode Leaflet di SMK Bina Dirgantara Karanganyar (Skripsi). Surakarta: Universitas Muhammadiyah Surakarta; 2014.

7. Oktarina J, Margono HM, Purnomo W. Pengaruh Pendidikan Kesehatan Reproduksi oleh Sebaya terhadap Pengetahuan dan Sikap dalam Pencegahan Seks Pranikah di SMAN 1 Sukamara, Kabupaten Sukamara, Kalimantan Tengah. Buletin Penelitian Sistem Kesehatan. Januari 2017; 20 (1): 26-33.

8. Kasih LC. Efektifitas Peer Education pada Pengetahuan dan Sikap Siswa SMA dalam Pencegahan HIV/AIDS. Jurnal Ilmu Keperawatan. 2015. ISSN: 2338-6371.

9. Notoatmodjo S. Ilmu Perilaku Kesehatan. Jakarta: Rineka Cipta; 2010.
10. Rahmawati I, Sudayo T, Paramatri. Pengaruh Penyuluhan dengan Media Audio Visual terhadap Peningkatan Pengetahuan, Sikap, dan Perilaku Ibu Balita Gizi Kurang dan Buruk di Kabupaten Kotawaringin Barat Propinsi Kalimantan Tengah. Jurnal Gizi Klinik Indonesia. November 2007; 4 (2).

11. Marlita L. Pengaruh Peer Education terhadap Perilaku Seksual Remaja di SMAK Abdurrab Kota Pekanbaru Provinsi Riau. Jurnal Keperawatan. Januari 2016; 11 (3): 127-131.

12. Suhertusi B, Desmiwarti, Nurjasmi E. Pengaruh Media Promosi Kesehatan tentang ASI Eksklusif terhadap Peningkatan Pengetahuan Ibu di Wilayah Kerja Puskesmas Lubuk Begalung Padang Tahun 2014. Jurnal Kesehatan Andalas. 2015; 4 (1).

13. Hariyatmoko T. Pengaruh Pendidikan Kesehatan Reproduksi dengan Metode Ceramah dan Leaflet terhadap Pengetahuan pada Remaja di Madrasah Aliyah Yapim Ngeluk Penawangan Kabupaten Grobogan (Skripsi). Surakarta: Universitas Muhammadiyah Surakarta; 2012.

14. Marlian J. Pengaruh Pendidikan Proteksi Pornografi melalui Video dan Komik terhadap Perilaku Seks Remaja di SMKN Jakarta (Tesis). Semarang: Universitas Diponegoro; 2016.

15. Hurlock EB. Psikologi Perkembangan. Jakarta: Erlangga; 2011. 